\title{
ANALISIS TROPHIC STATE INDEX CARLSON AIR MUARA SUNGAI BANJIR KANAL TIMUR, SEMARANG
}

\author{
Analysis of Carlson Trophic State Index for East Banjir Kanal Estuary, Semarang
}

\section{Andro Khasani, Norma Afiati*) dan Bambang Sulardiono}

Program Studi Manajemen Sumberdaya Perairan, Departemen Sumberdaya Akuatik

Fakultas Perikanan dan Ilmu Kelautan, Universitas Diponegoro

J1. Prof. Soedarto, SH, Tembalang, Semarang, Jawa Tengah - 50275, Telp/Fax. +6224 7474698

Email : androkhasani21@gmail.com

\begin{abstract}
ABSTRAK
Sungai Banjir Kanal Timur merupakan salah satu sungai besar yang dimiliki Kota Semarang. Sungai ini berfungsi dalam sistem drainase dan pengendalian banjir. Beberapa aliran sungai mengalir ke Sungai Banjir Kanal Timur dan berakhir di muara. Muara merupakan segmen yang akan menampung semua beban yang berasal dari sungai. Oleh karena itu, status trofik perairan di muara, khususnya Sungai Banjir Kanal Timur perlu dievaluasi dalam rangka pengelolaan lingkungan dan pemanfaatan sumberdaya alamnya. Penelitian ini dilaksanakan selama bulan Mei 2016 di muara Sungai Banjir Kanal Timur Semarang. Tujuan penelitian adalah untuk mengetahui kualitas air melalui status kesuburan perairan di muara Sungai Banjir Kanal Timur, berdasarkan metode Trophic State Index (Carlson, 1977) dan metode STORET dalam Kepmen LH No. 115 Tahun 2003 tentang Pedoman Penentuan Status Mutu Air dan PP RI No. 82 Tahun 2001 tentang Pengelolaan Kualitas Air dan Pengendalian Pencemaran Air. Variabel utama yang digunakan pada Analisis TSI Carlson adalah kandungan total N, total P, klorofil-a, dan kecerahan air (angka Secchi disk). Metode penelitian menggunakan metode deskriptif dengan penentuan lokasi sampling bersifat purposive sampling. Hasil yang diperoleh dari analisis TSI (Carlson, 1977) berkisar 53 - 57. Kriteria TSI menunjukkan bahwa TSI TP $<$ TSI SD $>$ TSI CHL dan TSI TP > TSI SD > TSI CHL. Pendugaan interpretasi hubungan tersebut menjelaskan bahwa fosfor membatasi biomasa alga (rasio TN/TP lebih besar dari 33:1), dan nilai TSI Chl yang rendah disebabkan beberapa faktor lain selain fosfor seperti, pemangsaan oleh zooplankton, kandungan nitrogen, dan sebagainya yang sifatnya mengurangi biomasa algae. Di sisi lain, analisis (Indeks STORET) menggunakan Kepmen LH No. 115 Tahun 2003 tentang Pedoman Penentuan Status Mutu Air menghasilkan skor, yaitu -8. Berdasarkan hasil penelitian dapat disimpulkan bahwa kesuburan perairan muara Sungai Banjir Kanal Timur, Semarang menurut TSI (Carlson 1977) berada pada status eutrofik ringan atau (Indeks STORET, Kepmen LH No. 115 / 2003) termasuk kategori perairan tercemar ringan.
\end{abstract}

Kata Kunci : Status Mutu Perairan, Trophic State Index Carlson (1977), Kepmen LH No. 115 Tahun 2003, muara Sungai Banjir Kanal Timur Semarang.

\section{ABSTRACT}

East Banjir Kanal River is one of the largest river owned by the city of Semarang. The river has a main function as drainage system and flood control of the city. Several streams flowing into the East Banjir Kanal River and end at the estuary. As estuary accommodates all loads from the river, therefore, the trophic status of waters in particular for East Banjir Kanal River needs to be evaluated in the context of environmental management and utilization of natural resources. This work was conducted during May 2016 in the estuary of East Banjir Kanal River. The objective was to determine river water quality using Trophic State Index by Carlson (1977) and the STORET method in the Decree of the Minister of Environment of The Republic of Indonesia (Kepmen LH) No. 115/2003 regarding Guideline for the Determination of Water Quality Status and The Government Regulation of The Republic of Indonesia No 81/2001 regarding Water Quality Management and Water Pollution Control. The main variables used in the analysis of Trophic State Index by Carlson, 1977 are total N, total P, chlorophyll-a and water clarity. Descriptive method is used to determine random sampling points. The average results of all stations analysed by means of Trophic State Index (Carlson, 1977) ranged from 53-57. The interpretation showed that TSI TP $<$ TSI SD $>$ TSI CHL and TSI TP $>$ TSI SD $>$ TSI CHL, these mean that phosphorus limit the biomass of algae (the ratio TN/TP larger than 33:1). Furthermore, lower TSI Chl values in all sampling point were due to several factors other than phosphorus, such as predatory zooplankton, nitrogen which worked to reduce algal biomass. The STORET analysis in the Decree of the Minister of Environment of The Republic of Indonesia (Kepmen LH) No. 115/2003 about Guideline for the Determination of Water Quality Status gives an overall score of minus 8. It is concluded that by applying both methods, the estuary of the East Banjir Kanal, Semarang during the course of the study were on light eutrophic status and categorized as lightly polluted waters.

Keywords: Water Quality Status, Trophic State Index Carlson (1977), Decree of the Minister of Environment of The Republic Indonesia (Kepmen LH) No. 115/2003, Estuary of East Banjir Kanal River Semarang.

*) Penulis penanggungjawab

${ }^{\circ}$ Copyright by Management of Aquatic Resources (MAQUARES) 


\section{PENDAHULUAN}

Sungai Banjir Kanal Timur merupakan salah satu sungai (kanal) besar yang dimiliki Kota Semarang. Sungai ini merupakan salah satu sistem drainase yang ada di bagian wilayah Kota Semarang timur. Sistem drainase Sungai Banjir Kanal Timur memiliki fungsi sebagai sungai pembuangan yang mengumpulkan sungai-sungai pembuangan lain dan sebagai sistem pengendalian banjir Kota Semarang.

Sungai Banjir Kanal Timur merupakan salah satu sistem drainase yang ada di Kota Semarang. Sungai ini adalah salah satu dari dua sungai (kanal) besar yang dimiliki Kota Semarang yaitu Banjir Kanal Barat dan Banjir Kanal Timur. Sungai Banjir Kanal Timur berdasarkan Undang-Undang (UU) No.11 tahun 1974 tentang pengairan, UU No. 22 Tahun 1999 tentang Pemerintah Daerah adalah sistem sungai Penggaron, termasuk anak sungai: Kali Kedung Mundu, Kali Candi, Kali Bajak sampai Sungai Banjir Kanal Timur ke muara merupakan sungai lintas Kabupaten/Kota yaitu lintas Kabupaten Semarang, Kota Semarang, dan Kabupaten Demak, sehingga menjadi aset Daerah Provinsi Jawa Tengah. Sungai BKT ini memiliki kemiringan yang landai (Anggani, 2005).

Daerah muara sungai akan mengalami dampak yang sangat besar. Muara sungai akan menampung beban yang berasal dari seluruh aliran sungai sehingga apabila muara sungai mengalami beban pencemaran yang berat dan terjadi kerusakan secara ekologis maka akan mempengaruhi ekosistem lainnya khususnya ekosistem pesisir dan laut. Menurut Anggraeni et al. (2014), muara sungai merupakan bagian daerah pesisir yang memainkan peranan penting secara ekonomi, ekologi dan juga merupakan kawasan dengan ekosistem komplek. Menurut Muchtar (2002), perkembangan perkotaan, penduduk dan industri selain memberikan dampak yang positif juga memberikan dampak yang negatif terhadap perairan sekelilingnya. Limbah rumah tangga dan limbah-limbah industri yang akhirnya bermuara sampai ke laut dapat merubah kondisi perairan tersebut.

Kondisi suatu perairan atau kualitas perairan dapat ditinjau dari berbagai aspek salah satunya adalah tingkat kesuburan perairan. Tingkat kesuburan perairan yang terlalu tinggi atau terlalu rendah dapat mempengaruhi kondisi di suatu perairan tersebut. Berbagai macam bentuk pembuangan limbah rumah tangga, limbah industri, dan limbah lainnya baik sengaja maupun tidak disengaja yang terhanyut oleh aliran sungai khususnya Sungai Banjir Kanal Timur terakumulasi di daerah muara sehingga diduga dapat mempengaruhi tingkat kesuburan muara Sungai Banjir Kanal Timur. Menurut Suryono, et al. (2010), eutrofikasi atau sering disebut pengkayaan unsur hara dalam perairan dapat mengakibatkan perairan menjadi subur. Proses eutrofikasi sendiri merupakan proses alami yang akan terjadi pada setiap perairan tergenang namun dalam waktu yang cukup lama. Seiring dengan meningkatnya aktivitas masyarakat, maka akan memberikan masukan berupa unsur hara ke badan air sungai dan jika proses pulih diri (self purification) terlampaui maka akan mempercepat proses eutrofikasi.

Variabel yang digunakan pada penelitian ini adalah klorofil-a, total N, dan total P yang merupakan indikator status trofik suatu perairan. Analisis tingkat kesuburan perairan pada penelitian ini menggunakan Analisis Trophic State Index (Carlson, 1977) yang selanjutnya disingkat TSI (Carlson, 1977), merupakan indeks yang dikembangkan untuk mengetahui tingkat kesuburan perairan berdasarkan beberapa parameter yang berpengaruh, sehingga memudahkan dalam mengetahui kondisi perairan. Penelitian tentang Analisis Trophic State Index air muara Sungai Banjir Kanal Timur Semarang sangat perlu dilakukan untuk mengetahui kondisi perairan muara Sungai Banjir Kanal Timur ditinjau dari tingkat kesuburan perairan (Oligotrophic, Mesotrophic, Eutrophic, Hypereutrophic).

\section{MATERI DAN METODE PENELITIAN}

\section{A. Materi Penelitian}

Materi yang digunakan pada penelitian ini adalah air sungai Banjir Kanal Timur, Semarang. Air sungai tersebut digunakan sebagai materi pengukuran variabel fisika-kimia-biologi, khususnya total N, total P, kedalaman Secchi, dan klorofil-a yang terangkum sebagai variabel kunci dalam analisis TSI (Carlson, 1977). Variabel fisika-kimia lainnya adalah suhu air, kedalaman, arus, oksigen terlarut, salinitas, dan $\mathrm{pH}$.

\section{B. Metode Penelitian}

Metode penelitian bersifat deskriptif yaitu metode yang digunakan untuk mencari unsur-unsur, ciri-ciri, sifatsifat suatu fenomena dimulai dengan mengumpulkan data, menganalisis data dan menginterpretasikannya (Suryana, 2010). Dalam penelitian ini subjeknya adalah status trofik perairan sungai Banjir Kanal Timur, Semarang.

\section{Penentuan Lokasi Sampling}

Penentuan lokasi titik sampling ditentukan menggunakan metode "Purposive Sampling". Penentuan titik sampel ditentukan berdasarkan wilayah yang diperkirakan telah mewakili perairan muara sungai Banjir Kanal Timur. Pengambilan titik sampel dilakukan mulai dari muara hingga tersebar di sekitar muara serta menuju ke arah laut. Titik 1 berada di sungai, titik 2 berada tepat di pertemuan dua aliran sungai Banjir Kanal Timur dan Sungai Tenggang, titik 3 berada di timur muara, titik 4 berada di barat muara, dan titik 5 berada tepat di mulut muara.

\section{Teknik Pengambilan Sampel}

Teknik pengambilan air sampel ditetapkan dengan ketentuan: angka intensitas cahaya di kedalaman saat Secchi disc tidak terlihat (Iz) 10\% dari angka intensitas cahaya di permukaan air (Io). Ketentuan tersebut menurut Hutchinson, 1957 dalam Carlson (1977), (Iz) yaitu 10\% dari (Io). Berdasarkan ketentuan tersebut, sampel air diambil di kedalaman $1 \mathrm{~m}$. 


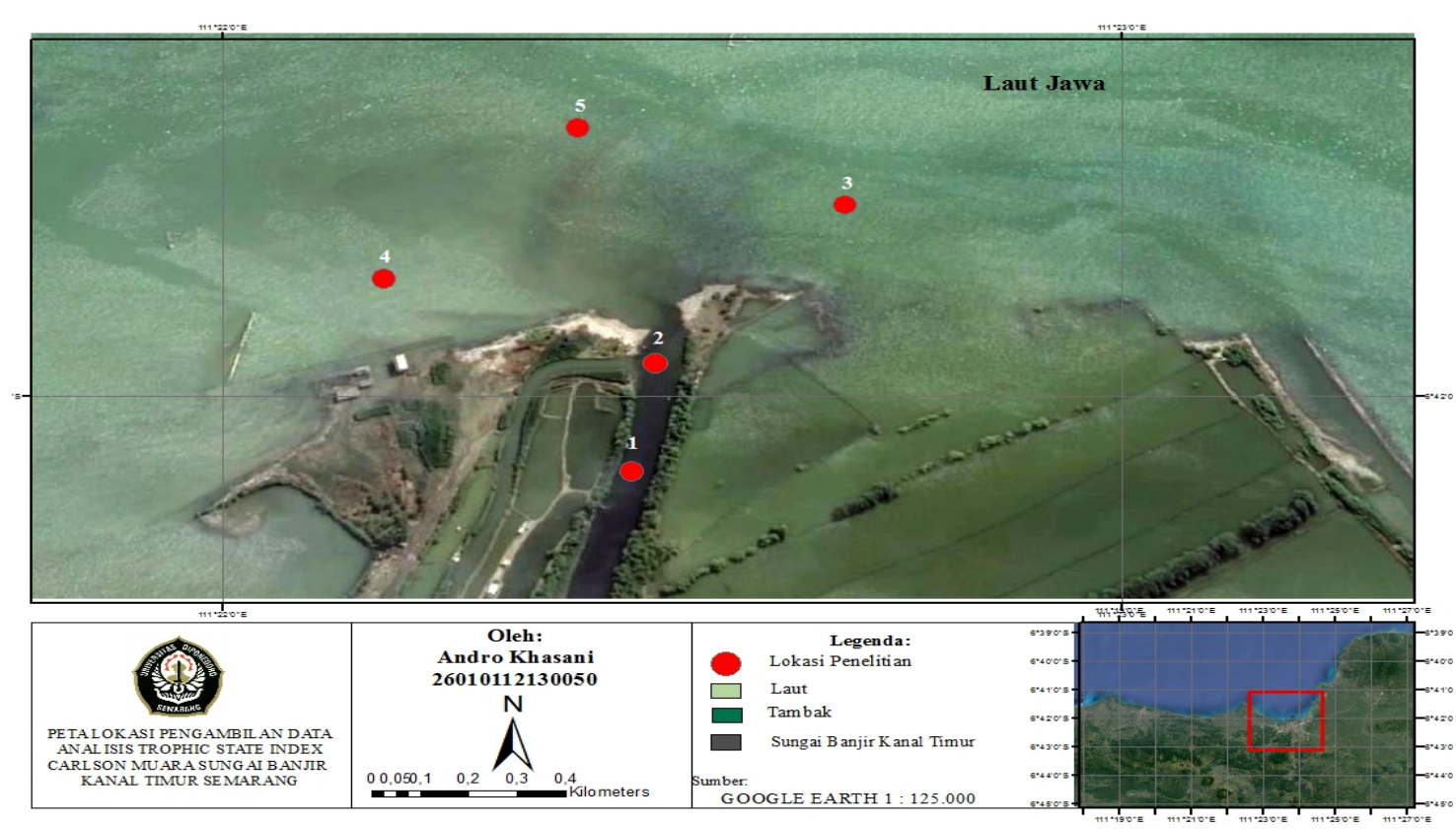

Gambar 1. Peta Lokasi Penelitian

Sumber: Google Earth, Mei 2016

\section{Analisis Data}

Data klorofil-a, total P, dan kedalaman Secchi yang diperoleh dari penelitian diolah dengan rumus TSI (Carlson, 1977). Variabel fisika kimia antara lain: suhu, total $\mathrm{N}$, total $\mathrm{P}, \mathrm{pH}$, salinitas, dan oksigen terlarut digunakan untuk menentukan status mutu air berdasarkan Kepmen LH No. 115 tahun 2003 tentang Pedoman Penentuan Status Mutu Air. Dalam Kepmen LH No. 115 tahun 2003 tentang Pedoman Penentuan Status Mutu Air, digunakan indeks STORET. Angka-angka hasil pengukuran variabel fisika-kimia air dibandingkan dengan angka baku mutu berdasarkan PP RI No. 82 Tahun 2001 tentang Pengelolaan Kualitas Air dan Pengendalian Pencemaran Air kategori kelas II.

\section{HASIL DAN PEMBAHASAN}

A. Hasil

Hasil pengukuran fisika, kimia, dan biologi perairan sebagai berikut:

Tabel 1. Suhu Air, Kecerahan, Kedalaman, Arus, pH, Salinitas, dan Oksigen pukul 08.00 - 11.00 WIB di Sungai Banjir Kanal Timur Semarang Mei, 2016

\begin{tabular}{|c|c|c|c|c|c|c|}
\hline \multirow{2}{*}{ Waktu Sampling } & \multirow{2}{*}{ Variabel } & \multicolumn{5}{|c|}{ Stasiun } \\
\hline & & $\mathbf{I}$ & II & III & IV & $\mathbf{V}$ \\
\hline \multirow{7}{*}{17 Mei 2016} & Suhu air $\left({ }^{\circ} \mathrm{C}\right)$ & 32 & 32 & 31 & 30 & 31 \\
\hline & Kecerahan (m) & 0,49 & 0,46 & 0,58 & 0,50 & 0,45 \\
\hline & Kedalaman (m) & 2,01 & 2,49 & 1,48 & 0,85 & 0,94 \\
\hline & Kecepatan Arus (m/s) & 0,03 & 0,25 & 0,07 & 0,33 & 0,07 \\
\hline & $\mathrm{pH}$ & 7 & 7 & 7 & 7 & 7 \\
\hline & Salinitas $(\% / 00)$ & 8 & 15 & 20 & 28 & 25 \\
\hline & Oksigen terlarut $(\mathrm{mg} / \mathrm{l})$ & 3,5 & 4,7 & 8 & 4,8 & 6,2 \\
\hline \multirow{7}{*}{24 Mei 2016} & Suhu air $\left({ }^{\circ} \mathrm{C}\right)$ & 30 & 31 & 31 & 31 & 30 \\
\hline & Kecerahan (m) & 0,40 & 0,41 & 0,40 & 0,38 & 0,28 \\
\hline & Kedalaman (m) & 2,23 & 2,56 & 1,16 & 1,03 & 1,27 \\
\hline & Kecepatan Arus (m/s) & 0,01 & 0,25 & 0,07 & 0,14 & 0,12 \\
\hline & $\mathrm{pH}$ & 7 & 7 & 7 & 7 & 7 \\
\hline & Salinitas $(\% / 00)$ & 5 & 5 & 30 & 30 & 15 \\
\hline & Oksigen terlarut $(\mathrm{mg} / \mathrm{l})$ & 5 & 4 & 5,2 & 5,4 & 3,2 \\
\hline \multirow{7}{*}{31 Mei 2016} & Suhu air $\left({ }^{\circ} \mathrm{C}\right)$ & 31 & 31 & 31 & 31 & 31 \\
\hline & Kecerahan (m) & 0,26 & 0,28 & 0,16 & 0,21 & 0,18 \\
\hline & Kedalaman (m) & 1,04 & 1,58 & 0,90 & 0,98 & 0,38 \\
\hline & Kecepatan Arus (m/s) & 0,02 & 0,25 & 0,08 & 0,12 & 0,20 \\
\hline & $\mathrm{pH}$ & 7 & 7 & 7 & 6 & 6 \\
\hline & Salinitas $(\% / 00)$ & 2 & 5 & 25 & 28 & 17 \\
\hline & Oksigen terlarut (mg/l) & 2,8 & 3,8 & 4,4 & 6,2 & 4 \\
\hline
\end{tabular}

\footnotetext{
${ }^{\circledR}$ Copyright by Management of Aquatic Resources (MAQUARES)
} 
Suhu perairan muara Sungai Banjir Kanal Timur berkisar $30-32^{\circ} \mathrm{C}$. Kecerahan air di setiap stasiunnya berkisar $15-50 \mathrm{~cm}$. Hasil pengukuran kecepatan arus di setiap stasiunnya $0,01-0,33 \mathrm{~m} / \mathrm{s}$. Hasil pengukuran $\mathrm{pH}$ di setiap stasiunnya berkisar $6-7 \mathrm{~m} / \mathrm{s}$. Oksigen Terlarut di setiap stasiunnya berkisar $2,8-8 \mathrm{mg} / \mathrm{l}$. Salinitas di setiap stasiunnya berkisar $2-30 \mathrm{ppm}$ (Tabel 1).

\section{Total N}

Tabel 2. Hasil Pengukuran Total N ( $\mu \mathrm{g} / \mathrm{L})$ pukul 08.00 - 11.00 WIB di Muara Sungai Banjir Kanal Timur Mei, 2016

\begin{tabular}{cccccc}
\hline \multirow{2}{*}{ Pengulangan } & \multicolumn{5}{c}{ Stasiun } \\
\cline { 2 - 5 } & I & II & III & IV & V \\
\hline 1 & 4803 & 6083 & 5123 & 4162 & 2241 \\
2 & 2557 & 3516 & 1918 & 2237 & 1598 \\
3 & 3839 & 3518 & 6062 & 2552 & 3509 \\
\hline
\end{tabular}

Hasil yang diperoleh menunjukkan konsentrasi Total N di muara Sungai Banjir Kanal Timur Semarang berkisar 1598 - $6083 \mu \mathrm{g} / \mathrm{L}$. Jumlah konsentrasi Total N di muara Banjir Kanal Timur berbeda-beda di setiap stasiunnya, dan berfluktuatif pada setiap pengulangannya. Konsentrasi Total $\mathrm{N}$ di stasiun I, II, dan III memiliki nilai yang tinggi dibandingkan di stasiun IV, dan V. Fluktuasi yang terjadi pada konsentrasi total N di muara Sungai Banjir Kanal Timur Semarang dipengaruhi oleh sumber nutrien (nitrogen) yang masuk ke dalam muara tersebut. Sumber nutrien fosfor yang masuk diduga berasal dari kegiatan perikanan (tambak) yang berada di sekitar muara dan berasal dari kegiatan masyarakat seperti hasil limbah domestik dan kegiatan manifaktur di sekitar aliran sungai. Tingginya konsetrasi total $\mathrm{P}$ di stasiun I, II, dan III membuktikan unsur nitrogen yang masuk ke muara Sungai Banjir Kanal Timur berasal dari sungai, yaitu Sungai Banjir Kanal Timur dan Sungai Tenggang. Secara umum jumlah konsentrasi Total N di perairan muara Banjir Kanal Timur tergolong tinggi, sehingga mempengaruhi jumlah konsentrasi klorofil-a yang menyebabkan kesuburan perairan menjadi meningkat.

\section{Total P}

Tabel 3. Hasil Pengukuran Total P $(\mu \mathrm{g} / \mathrm{L})$ pukul 08.00 - 11.00 WIB di Muara Sungai Banjir Kanal Timur Mei, 2016

\begin{tabular}{cccccc}
\hline \multirow{2}{*}{ Pengulangan } & \multicolumn{5}{c}{ Stasiun } \\
\cline { 2 - 6 } & I & II & III & IV & V \\
\hline 1 & 65 & 188 & 142 & 173 & 45 \\
2 & 155 & 9 & 15 & 13 & 73 \\
3 & 350 & 170 & 63 & 44 & 86 \\
\hline
\end{tabular}

Hasil yang diperoleh pada uji total P di muara Sungai Banjir Kanal Timur Semarang berkisar $9-350 \mu \mathrm{g} / \mathrm{L}$. Jumlah konsentrasi total P di muara Banjir Kanal Timur berbeda-beda di setiap stasiunnya, dan berfluktuatif pada setiap pengulangannya. Konsentrasi total P di stasiun I, dan II memiliki nilai yang tinggi dibandingkan di stasiun lainnya. Fluktuasi yang terjadi pada konsentrasi total P di muara Sungai Banjir Kanal Timur Semarang dipengaruhi oleh sumber nutrien fosfor yang masuk ke dalam muara tersebut. Sumber nutrien fosfor yang masuk diduga berasal dari kegiatan perikanan (tambak) yang berada di sekitar muara dan berasal dari kegiatan masyarakat seperti hasil limbah domestik (detergen) dan kegiatan manifaktur di sekitar aliran sungai. Tingginya konsetrasi total P di stasiun I dan II membuktikan unsur fosfor yang masuk ke muara Sungai Banjir Kanal Timur sebagian besar berasal dari aliran Sungai Banjir Kanal Timur dan Sungai Tenggang.

\section{Klorofil-a}

Tabel 4. Hasil Pengukuran Klorofil-a ( $\mu \mathrm{g} / \mathrm{l})$ pukul 08.00 - 11.00 WIB di Muara Sungai Banjir Kanal Timur Mei, 2016

\begin{tabular}{cccccc}
\hline \multirow{2}{*}{ Pengulangan } & \multicolumn{5}{c}{ Stasiun } \\
\cline { 2 - 6 } & I & II & III & IV & V \\
\hline 1 & 1,5412 & 2,9793 & 1,8938 & 2,6313 & 1,8384 \\
2 & 0,0253 & 0,0610 & 0,1951 & 0,0813 & 0,0593 \\
3 & 0,8165 & 1,3090 & 0,6719 & 0,9127 & 0,7857 \\
\hline
\end{tabular}

Hasil yang diperoleh menunjukkan konsentrasi klorofil-a di muara Sungai Banjir Kanal Timur Semarang berkisar $0,0253-2,9793 \mu \mathrm{g} / \mathrm{L}$. Hasil tersebut menunjukkan bahwa perairan tersebut tergolong baik, karena tidak ditemukannya kondisi blooming algae. Kondisi blooming algae salah satunya ditandai dengan jumlah fitoplankton yang melimpah dan warna air yang cenderung berwarna hijau, sedangkan di muara Banjir Kanal Timur tidak ditemukan tanda-tanda tersebut. Jumlah konsentrasi klorofil-a di muara Banjir Kanal Timur dikategorikan ke dalam kondisi yang cukup baik. Konsentrasi klorofil-a akan mempengaruhi tingkat kesuburan muara Banjir Kanal Timur. 


\section{Trophic State Index Carlson}

Tabel 5. Hasil Analisis Trophic State Index Carlson (1977) pukul 08.00 - 11.00 WIB di Muara Sungai Banjir Kanal Timur Mei, 2016

\begin{tabular}{cccccccr}
\hline \multirow{2}{*}{ Stasiun } & $\begin{array}{c}\text { Minggu } \\
\text { ke- }\end{array}$ & $\begin{array}{c}\text { Total P } \\
(\boldsymbol{\mu g} / \mathbf{l})\end{array}$ & $\begin{array}{c}\text { Secchi } \text { depth } \\
(\mathbf{m})\end{array}$ & $\begin{array}{c}\text { Klorofil-a } \\
(\boldsymbol{\mu g} / \mathbf{l})\end{array}$ & $\begin{array}{c}\text { TSI } \\
\text { TP }\end{array}$ & $\begin{array}{c}\text { TSI } \\
\text { SD }\end{array}$ & $\begin{array}{c}\text { TSI } \\
\text { Chl a }\end{array}$ \\
\hline I & 1 & 65 & 0,49 & 1,54 & 64,34 & 70,28 & 34,84 \\
& 2 & 155 & 0,41 & 0,03 & 76,88 & 73,02 & $-5,46$ \\
& 3 & 350 & 0,26 & 0,82 & 88,62 & 79,41 & 28,61 \\
II & 1 & 188 & 0,46 & 2,98 & 79,66 & 71,35 & 41,31 \\
& 2 & 9 & 0,41 & 0,06 & 35,83 & 72,85 & 3,15 \\
& 3 & 170 & 0,28 & 1,31 & 78,21 & 78,34 & 33,24 \\
III & 1 & 142 & 0,59 & 1,89 & 75,61 & 67,73 & 36,86 \\
& 2 & 15 & 0,40 & 0,20 & 43,20 & 73,20 & 14,57 \\
& 3 & 63 & 0,16 & 0,67 & 63,89 & 86,86 & 26,70 \\
IV & 1 & 173 & 0,50 & 2,63 & 78,46 & 70,13 & 40,09 \\
& 2 & 13 & 0,38 & 0,08 & 41,14 & 73,94 & 5,98 \\
& 3 & 44 & 0,21 & 0,91 & 58,72 & 82,49 & 29,70 \\
V & 1 & 45 & 0,45 & 1,84 & 59,04 & 71,51 & 36,57 \\
& 2 & 73 & 0,28 & 0,06 & 66,02 & 78,60 & 2,88 \\
& 3 & 86 & 0,19 & 0,79 & 68,38 & 84,32 & 28,23 \\
\hline
\end{tabular}

Tabel 6. Interpretasi Analisis Data Muara Sungai Banjir Kanal Timur Semarang menurut TSI Carlson (1977) Mei, 2016

\begin{tabular}{|c|c|c|c|}
\hline Stasiun & $\begin{array}{l}\text { Minggu } \\
\text { ke- }\end{array}$ & Hubungan TSI & Interpretasi Menurut Carlson (1977) \\
\hline \multirow[t]{3}{*}{$\mathrm{I}$} & 1 & TSI TP $<$ TSI SD $>$ TSI CHL & $\begin{array}{l}\text { Fosfor membatasi biomasa algae (rasio } \mathrm{TN} / \mathrm{TP} \\
\text { lebih besar dari } 33: 1 \text { ) }\end{array}$ \\
\hline & 2 & TSI TP $>$ TSI SD $>$ TSI CHL & $\begin{array}{l}\text { Beberapa faktor lain selain fosfor (pemangsaan } \\
\text { zooplankton, nitrogen, dan sebagainya) } \\
\text { mengurangi biomasa algae }\end{array}$ \\
\hline & 3 & TSI TP > TSI SD > TSI CHL & $\begin{array}{l}\text { Beberapa faktor lain selain fosfor (pemangsaan } \\
\text { zooplankton, nitrogen, dan sebagainya) } \\
\text { mengurangi biomasa algae }\end{array}$ \\
\hline \multirow[t]{3}{*}{ II } & 1 & TSI TP $>$ TSI SD $>$ TSI CHL & $\begin{array}{l}\text { Beberapa faktor lain selain fosfor (pemangsaan } \\
\text { zooplankton, nitrogen, dan sebagainya) } \\
\text { mengurangi biomasa algae }\end{array}$ \\
\hline & 2 & TSI TP $<$ TSI SD $>$ TSI CHL & $\begin{array}{l}\text { Fosfor membatasi biomasa algae (rasio TN/TP } \\
\text { lebih besar dari } 33: 1 \text { ) }\end{array}$ \\
\hline & 3 & TSI TP $=$ TSI SD $>$ TSI CHL & $\begin{array}{l}\text { Partikel non-alga atau warna terlarut mendominasi } \\
\text { penurunan cahaya }\end{array}$ \\
\hline \multirow[t]{3}{*}{ III } & 1 & TSI TP > TSI SD > TSI CHL & $\begin{array}{l}\text { Beberapa faktor lain selain fosfor (pemangsaan } \\
\text { zooplankton, nitrogen, dan sebagainya) } \\
\text { mengurangi biomasa algae }\end{array}$ \\
\hline & 2 & TSI TP $<$ TSI SD $>$ TSI CHL & $\begin{array}{l}\text { Fosfor membatasi biomasa algae (rasio TN/TP } \\
\text { lebih besar dari 33:1) }\end{array}$ \\
\hline & 3 & TSI TP $<$ TSI SD $>$ TSI CHL & $\begin{array}{l}\text { Fosfor membatasi biomasa algae (rasio TN/TP } \\
\text { lebih besar dari } 33: 1 \text { ) }\end{array}$ \\
\hline \multirow[t]{3}{*}{ IV } & 1 & TSI TP > TSI SD > TSI CHL & $\begin{array}{l}\text { Beberapa faktor lain selain fosfor (pemangsaan } \\
\text { zooplankton, nitrogen, dan sebagainya) } \\
\text { mengurangi biomasa algae }\end{array}$ \\
\hline & 2 & TSI TP $<$ TSI SD $>$ TSI CHL & $\begin{array}{l}\text { Fosfor membatasi biomasa algae (rasio TN/TP } \\
\text { lebih besar dari 33:1) }\end{array}$ \\
\hline & 3 & TSI TP < TSI SD > TSI CHL & $\begin{array}{l}\text { Fosfor membatasi biomasa algae (rasio TN/TP } \\
\text { lebih besar dari 33:1) }\end{array}$ \\
\hline \multirow[t]{3}{*}{$\mathrm{V}$} & 1 & TSI TP $<$ TSI SD $>$ TSI CHL & $\begin{array}{l}\text { Fosfor membatasi biomasa algae (rasio TN/TP } \\
\text { lebih besar dari } 33: 1 \text { ) }\end{array}$ \\
\hline & 2 & TSI TP $<$ TSI SD $>$ TSI CHL & $\begin{array}{l}\text { Fosfor membatasi biomasa algae (rasio TN/TP } \\
\text { lebih besar dari 33:1) }\end{array}$ \\
\hline & 3 & TSI TP < TSI SD > TSI CHL & $\begin{array}{l}\text { Fosfor membatasi biomasa algae (rasio TN/TP } \\
\text { lebih besar dari 33:1) }\end{array}$ \\
\hline
\end{tabular}


Untuk menyederhanakan interpretasi (Carlson, 1977), maka data Tabel 6. dirata-rata sehingga interpretasi Carlson yang diperoleh pada data Hubungan TSI muara Sungai Banjir Kanal Timur, yaitu fosfor membatasi biomassa algae (rasio TN/TP lebih besar dari 33:1), dan beberapa faktor lain selain fosfor (pemangsaan zooplankton, nitrogen dan sebagainya mengurangi biomassa algae.

Tabel 7. Hasil Interpretasi Status Trofik Analisis Trophic State Index Carlson (1977) pukul 08.00 - 11.00 WIB di Muara Sungai Banjir Kanal Timur Mei, 2016

\begin{tabular}{ccccc}
\hline Stasiun & Minggu ke- & TSI & Rerata & Status Trofik \\
\hline I & 1 & 56 & 57 & Eutrofik ringan \\
& 2 & 48 & & \\
3 & 66 & 54 & Eutrofik ringan \\
II & 1 & 64 & & \\
& 2 & 63 & 54 & Eutrofik ringan \\
III & 3 & 60 & & Eutrofik ringan \\
& 1 & 44 & 53 & Eutrofik ringan \\
IV & 3 & 59 & & \\
& 1 & 63 & 55 & \\
\end{tabular}

\section{Metode STORET (Kepmen LH No. 115 Tahun 2003)}

Hasil Analisis STORET (Kepmen LH No. 115 Tahun 2003) di muara Sungai Banjir Kanal Timur dapat dilihat pada Tabel 8 .

Tabel 8. Hasil Analisis STORET (Kepmen LH No. 115 Tahun 2003) berdasarkan Kriteria Mutu Air Kelas II PP No. 82 Tahun 2001 tentang Pengelolaan Kualitas Air dan Pengendalian Pencemaran Air pukul 08.00 - 11.00 WIB di Muara Sungai Banjir Kanal Timur, Mei 2016

\begin{tabular}{|c|c|c|c|c|c|c|c|}
\hline \multirow{2}{*}{ No. } & \multirow{2}{*}{ Parameter } & \multirow{2}{*}{ Satuan } & \multirow{2}{*}{ Kisaran Baku Mutu } & \multicolumn{3}{|c|}{$\begin{array}{r}\text { Hasil Pengukuran } \\
\end{array}$} & \multirow[t]{2}{*}{ Skor } \\
\hline & & & & Maksimum & Minimum & Rerata & \\
\hline & FISIKA & & & & & & \\
\hline 1. & $\begin{array}{c}\text { Suhu } \\
\text { KIMIA }\end{array}$ & ${ }^{\circ} \mathrm{C}$ & Deviasi $3^{\circ}$ & 32 & 30 & 31 & 0 \\
\hline 2. & $\mathrm{pH}$ & & $6-9$ & 7 & 6 & 7 & 0 \\
\hline 3. & DO & $\mathrm{mg} / \mathrm{L}$ & 4 & 8 & 2,8 & 4,8 & -4 \\
\hline 4. & Total P & $\mathrm{mg} / \mathrm{L}$ & 0,2 & 0,35 & 0,009 & 0,11 & -4 \\
\hline 5. & $\begin{array}{c}\text { Total N } \\
\text { BIOLOGI }\end{array}$ & $\mathrm{mg} / \mathrm{L}$ & 10 & 6,08 & 1,6 & 2,71 & 0 \\
\hline & & & Total Skc & & & & -8 \\
\hline
\end{tabular}




\section{Identifikasi Fitoplankton}

Tabel 9. Kelimpahan Fitoplankton (ind/L) di muara Sungai Banjir Kanal Timur Mei, 2016

\begin{tabular}{|c|c|c|c|c|c|c|c|c|c|c|c|c|c|c|c|c|}
\hline \multirow{3}{*}{ No. } & \multirow{3}{*}{ Genus } & \multicolumn{15}{|c|}{ Titik } \\
\hline & & \multicolumn{3}{|c|}{$\mathrm{I}$} & \multicolumn{3}{|c|}{ II } & \multicolumn{3}{|c|}{ III } & \multicolumn{3}{|c|}{ IV } & \multicolumn{3}{|c|}{$\mathrm{V}$} \\
\hline & & 1 & 2 & 3 & 1 & 2 & 3 & 1 & 2 & 3 & 1 & 2 & 3 & 1 & 2 & 3 \\
\hline & Bacillariophyceae & & & & & & & & & & & & & & & $\mathrm{V}$ \\
\hline 1. & Asterionella sp. & - & 9 & - & - & - & - & 49 & 4 & 15 & 72 & 15 & 23 & 42 & 25 & \\
\hline 2. & Biddulphia sp. & - & 23 & - & - & - & - & 9 & 27 & 6 & - & 10 & 2 & - & 11 & 7 \\
\hline 3. & Chaetoceros sp. & 4 & 6 & 11 & 6 & 9 & 15 & 721 & 693 & 664 & 312 & 678 & 821 & 531 & 626 & - \\
\hline 4. & Coscinodiscus sp. & 14 & 80 & 13 & 26 & 49 & 18 & 108 & 77 & 97 & 49 & 56 & 129 & 89 & 146 & 685 \\
\hline 5. & Guinardia sp. & - & 12 & - & - & 32 & - & 9 & 3 & 7 & 17 & 3 & 2 & 4 & 14 & 29 \\
\hline 6. & Melosira sp. & - & - & - & - & - & - & - & - & - & - & - & 4 & - & - & 1 \\
\hline 7. & Minidiscus sp. & 3 & 32 & 7 & - & 5 & - & 30 & 29 & 25 & 12 & 12 & 11 & 27 & 18 & - \\
\hline 8. & Navicula sp. & - & 13 & - & - & - & - & - & - & - & - & - & - & - & - & 14 \\
\hline 9. & Nitzschia sp. & 83 & 15 & 86 & 64 & 34 & 71 & 102 & 165 & 96 & 16 & 48 & 154 & 13 & 12 & - \\
\hline 10. & Noctiluca sp. & - & - & - & - & 22 & - & - & - & - & - & - & - & - & - & 41 \\
\hline 11. & Pleurosigma sp. & - & - & - & - & - & - & - & 33 & - & 3 & 13 & 3 & 6 & 19 & - \\
\hline 12. & Rhizosolenia sp. & - & - & - & - & - & - & 9 & 10 & 5 & & 27 & - & & 24 & 6 \\
\hline 13 & Skeletonema sp. & 4 & 4 & 8 & - & - & 17 & 17 & 7 & 35 & 57 & 65 & 49 & 82 & 43 & 4 \\
\hline 14. & Thalassionema sp. & - & - & - & - & - & - & 11 & 5 & 14 & - & - & 10 & 9 & 9 & 19 \\
\hline 15. & Thalassiosira sp. & - & - & - & - & - & - & 91 & 89 & 81 & - & - & 44 & - & - & 6 \\
\hline 16. & $\begin{array}{l}\text { Thalassiothrix sp. } \\
\text { Cyanophyceae }\end{array}$ & - & 7 & - & - & - & - & 255 & 8 & 80 & 20 & 10 & 144 & 24 & 33 & $\begin{array}{l}32 \\
75\end{array}$ \\
\hline 17. & $\begin{array}{l}\text { Trichodesmium sp. } \\
\text { Dinophyceae }\end{array}$ & 19 & 37 & 14 & - & 44 & - & 22 & 16 & 26 & 6 & 18 & 12 & 23 & 19 & 9 \\
\hline 18. & Ceratium sp. & - & 5 & - & - & - & - & - & 13 & - & 7 & 9 & 1 & - & 9 & \\
\hline 19. & $\begin{array}{l}\text { Protoperidinium } \\
\text { sp. }\end{array}$ & 4 & 10 & 7 & & 3 & - & 3 & 45 & 2 & 3 & 11 & 5 & 39 & 68 & 6 \\
\hline & Total & 121 & 253 & 146 & 97 & 198 & 121 & 1437 & 1224 & 1155 & 574 & 975 & 1414 & 889 & 1076 & 4 \\
\hline
\end{tabular}

Berdasarkan hasil identifikasi dan analisis data kelimpahan fitoplankton di muara Sungai Banjir Kanal Timur pada sampling pertama di setiap stasiun berkisar antara 90 - 1437 ind/l. Kelimpahan fitoplankton pada sampling kedua di setiap stasiun berkisar antara 195 - 1224 ind/l, dan kelimpahan fitoplankton pada sampling ketiga di setiap stasiun berkisar antara 106 - 1414 ind. Soegianto (1994) dalam Madinawati (2010), menjelaskan bahwa kelimpahan dengan nilai $<1.000 \mathrm{ind} / 1$ termasuk rendah, kelimpahan antara $1.000-40.000 \mathrm{ind} / 1$ tergolong sedang, dan kelimpahan $>40.000$ ind/1 tergolong tinggi. 


\section{Pembahasan}

Hasil analisis TSI Carlson di muara Sungai Banjir Kanal Timur Semarang berkisar 53 - 57. Hasil yang diperoleh, secara umum menunjukkan bahwa air muara Sungai Banjir Kanal Timur tergolong dalam status eutrofik ringan. Eutrofikasi yang terjadi di perairan muara Sungai Banjir Kanal Timur Semarang disebabkan oleh banyaknya unsur hara (nitrogen dan fosfor) masuk ke perairan tersebut. Hal ini ditunjukkan dengan tingginya konsentrasi Total $\mathrm{P}$ dan Total N (Tabel 2 - 3). Unsur hara yang masuk diduga berasal dari hasil limbah domestik maupun kegiatan masyarakat lainnya seperti, industri manufakturing, pertambakan, dan pertanian yang berasal aliran Sungai Banjir Kanal Timur dan Sungai Tenggang, karena kedua sungai tersebut berperan besar dalam menyumbang sebagian besar volume air muara Sungai Banjir Kanal Timur. Status perairan muara Sungai Banjir Kanal Timur Semarang tergolong eutrofik ringan, tetapi perairan tersebut masih tergolong aman bagi organisme di perairan tersebut. Hal ini dibuktikan dengan masih banyaknya kegiatan perikanan di muara Sungai Banjir Kanal Timur, seperti kegiatan nelayan (memancing dan menjaring ikan), dan kegiatan pertambakan (udang dan bandeng) yang memanfaatkan air tersebut. Hal ini diperkuat oleh Carlson (1977), bahwa kisaran angka TSI 50 - 60 tergolong dalam status eutrofik ringan, penurunan kecerahan air, zona hipolimnion bersifat anoksik, terjadi masalah tanaman air, hanya ikan-ikan yang mampu hidup di air hangat.

Hasil hubungan antar variabel TSI menunjukkan bahwa TSI-TP, TSI-TN dan TSI SD memiliki nilai yang lebih tinggi dibandingkan nilai TSI Chl (Tabel 6). TSI SD memiliki angka yang lebih tinggi daripada angka TSI Chl. Angka TSI TP cenderung hampir seimbang dengan angka TSI Chl akan tetapi angka TSI TP lebih tinggi dibandingkan angka TSI Chl. Nilai TSI TN lebih rendah dari nilai TSI-TP. Pendugaan interpretasi hasil analisis TSI Carlson (1977) menunjukkan bahwa fosfor membatasi biomasa alga (rasio TN/TP lebih besar dari 33:1), dan nilai TSI Chl yang rendah disebabkan beberapa faktor lain selain fosfor seperti, pemangsaan zooplankton, nitrogen, dan sebagainya akan mengurangi biomasa alga. Hal ini diperkuat oleh hasil regresi membuktikan bahwa Total $\mathrm{P}$ memiliki pengaruh yang signifikan terhadap klorofil-a. Menurut Carlson (2005), angka TSI SD yang lebih tinggi daripada angka TSI Chl membuktikan bahwa warna air mempengaruhi tingkat tranparansi air, tetapi warna air tidak mempengaruhi konsentrasi klorofil dan total phosphorus. Sedangkan angka TSI TP yang lebih tinggi daripada TSI Chl membuktikan bahwa terdapat faktor selain phosphorus yang mempengaruhi biomassa alga, misalnya pemangsaan zooplankton, nitrogen, dan sebagainya.

Hasil analisis metode STORET di muara Sungai Banjir Kanal Timur diperoleh skor -8. Skor tersebut menunjukkan status mutu air muara Sungai Banjir Kanal Timur tergolong Kelas B, yaitu tercemar ringan. Hal ini menjelaskan bahwa mutu air di muara Sungai Banjir Kanal Timur tergolong baik bagi lingkungan dan biota akuatik yang hidup di dalamnya serta masih dapat digunakan untuk kegiatan-kegiatan air khususnya kegiatan perikanan. Menurut Kepmen LH No. 115 Tahun 2003 tentang Pedoman Penentuan Status Mutu Air, metoda STORET adalah membandingkan antara data kualitas air dengan baku mutu air yang disesuaikan dengan peruntukannya guna menentukan status mutu air. Mutu air dengan skor -1 s/d -10 tergolong dalam Mutu Air Kelas B (Baik) tergolong tercemar ringan.

Hasil Trophic State Index Carlson dengan metode STORET Kepmen LH No. 115 tentang Pedoman Penentuan Status Mutu Air memiliki kesesuaian hasil. Hasil kedua metode ini menunjukkan bahwa muara Sungai Banjir Kanal Timur Semarang berada pada status eutrofik ringan atau tercemar ringan. Hal ini dibuktikan dengan tingginya unsur hara Total $\mathrm{P}$ dan Total $\mathrm{N}$ yang melebihi batas baku mutu air, akan tetapi masih belum berada pada status eutrofik berat atau tercemar berat, sehingga perairan muara Sungai Banjir Kanal Timur belum terdapat masalah tanaman air yang ekstensif, dan masih aman bagi kehidupan organisme di dalamnya. Banyak kegiatan perikanan yang dilakukan di muara Sungai Banjir Kanal Timur Semarang, seperti memancing, menjaring ikan, pertambakan, bagan sehingga hal tersebut membuktikan bahwa perairan muara Sungai Banjir Kanal Timur masih baik untuk mendukung kegiatan perikanan.

Analisis Trophic State Index Carlson dapat diterapkan sebagai salah satu alternatif dalam menentukan status kesuburan perairan tropis di tawar maupun laut. Hasil metode TSI Carlson tetap perlu dibandingkan dengan metode STORET Kepmen LH No. 115 tentang Pedoman Penentuan Status Mutu Air, sehingga dengan demikian diperoleh hasil yang representatif untuk menggambarkan status kesuburan suatu perairan, dalam hal ini air muara Sungai Banjir Kanal Timur Semarang.

\section{KESIMPULAN}

Kesimpulan yang dapat diambil dari penelitian ini adalah:

1. Status Kesuburan perairan di muara Sungai Banjir Kanal Timur, Kota Semarang, berdasarkan Trophic State Index Carlson menunjukkan status eutrofik ringan; dan

2. Status mutu air di muara Sungai Banjir Kanal Timur, Kota Semarang, berdasarkan Indeks STORET Kepmen LH No. 115 Tahun 2003 tentang Pedoman Penentuan Status Mutu Air dan PP RI No. 82 Tahun 2001 tentang Pengelolaan Kualitas Air dan Pengendalian Pencemaran Air adalah tercemar ringan (Tergolong Status B: baik). 


\section{UCAPAN TERIMA KASIH}

Penulis mengucapkan terima kasih kepada Ir. Siti Rudiyanti, M.Si., Dr. Ir. Pujiono W. Purnomo, MS., dan Dr. Ir. Max R. Muskananfola, M.Sc., yang telah memberikan arahan, bimbingan, serta kritik dan saran dalam penyusunan jurnal ini.

\section{DAFTAR PUSTAKA}

Anggani, H. 2005. Analisis Lingkungan Pemanfaatan Bantaran Sungai Banjir Kanal Timur. [Thesis]. Universitas Diponegoro, Semarang, $1-12 \mathrm{hlm}$.

Anggraeni, G., Suntoyo, dan Muhammad. 2014. Analisa Perubahan Kualitas Air Akibat Pembuangan Lumpur Sidoarjo pada Muara Kali Porong. Jurnal Teknik POMITS Vol. 2 (1), (2014) ISSN: 2337-3539 (2301-9271 Print).

Carlson, R. E. 1977. A Trophic State Index for Lakes. Limnology and Oceanography. Vol. 22 (2): 361-369 p.

2007. Estimating Trophic State. Spring/2007 Lakeline. 25-28 p.

Kepmen LH No. 115 Tahun 2003 tentang Pedoman Penentuan Status Mutu Air.

Madinawati. 2010. Kelimpahan dan Keanekaragaman Plankton di Perairan Laguna Desa Tolongano Kecamatan Banawa Selatan. Jurnal Media Litbang Sulawesi Tengah. Universitas Tadulako, Palu, Vol 3 (2): 119-123 hlm.

Muchtar, M. 2002. Distribusi Fosfat dan Nitrat di Perairan Kalimantan Timur. ISBN 979-8105-92-3.

Peraturan Pemerintah Republik Indonesia Nomor 82 Tahun 2001 tentang Pengelolaan Kualitas Air dan Pengendalian Pencemaran Air.

Suryana. 2010. Metodologi Penelitian. Universitas Pendidikan Indonesia. Bandung, $17 \mathrm{hlm}$.

Suryono, T., Senny, Endang, dan Rosidah. 2010. Tingkat Kesuburan dan Pencemaran Danau Limboto, Gorontalo. Oseanologi dan Limnologi di Indonesia (2010), Vol. 36 (1): 49-61 hlm. 